https://helda.helsinki.fi

The rational kernel within Samir Amin's mythological shell : the idea of a democratic and pluralist world political party

\title{
Patomaki, Heikki
}

$2019-11-10$

Patomaki , H 2019 , ' The rational kernel within Samir Amin's mythological shell : the idea of a democratic and pluralist world political party ' , Globalizations, vol. 16 , no. 7 , pp.

1006-1011 . https://doi.org/10.1080/14747731.2019.1651529

http://hdl.handle.net/10138/306888

https://doi.org/10.1080/14747731.2019.1651529

publishedVersion

Downloaded from Helda, University of Helsinki institutional repository.

This is an electronic reprint of the original article.

This reprint may differ from the original in pagination and typographic detail.

Please cite the original version. 


\section{Globalizations}

\section{The rational kernel within Samir Amin's mythological shell: the idea of a democratic and pluralist world political party}

\section{Heikki Patomäki}

To cite this article: Heikki Patomäki (2019) The rational kernel within Samir Amin's mythological shell: the idea of a democratic and pluralist world political party, Globalizations, 16:7, 1006-1011, DOI: $10.1080 / 14747731.2019 .1651529$

To link to this article: https://doi.org/10.1080/14747731.2019.1651529

曲 Published online: 21 Aug 2019.

Submit your article to this journal $\widetilde{ }$

Џ Article views: 205

Q View related articles $\widetilde{ }$

View Crossmark data $\asymp$ 


\title{
The rational kernel within Samir Amin's mythological shell: the idea of a democratic and pluralist world political party
}

\author{
Heikki Patomäki \\ Faculty of Social Sciences, University of Helsinki, Helsinki, Finland
}

\begin{abstract}
Amin's Leninist-Maoist vision is unlikely to be persuasive to twenty-first century citizens. Nonetheless, there is a rational kernel in Amin's call for a new worldwide political organization. Some structures, mechanisms and tendencies of the capitalist world economy are relatively enduring and some patterns recurrent, although the world economy is also fluid, constantly changing and evolving. Although waves of globalization have radically transformed human societies and their economic activities during the past 500 years also in many positive ways, the expansion of the international society and world economy has often been characterized by violence, imperial subjection and colonial expropriation and exclusion. There is a rational kernel also within Amin's analysis of the current world-political situation. Command over space and time by investors and megacorporations is power. Emancipation aims at freedom from domination. The decline of the World Social Forum indicates that progressive politics must move 'beyond the concept of a discussion forum'. My argument is that emancipation from unnecessary, unneeded and unwanted sources of determination requires global transformative agency and planetary visions about alternatives.
\end{abstract}

\section{KEYWORDS}

Capitalism; democracy; cosmopolitanism; Marx; mystical shell; tendential counterfactual thinking; World Social Forum; world political party

Samir Amin, a leading scholar and co-founder of the world-systems tradition, died on August 12, 2018. Just before his death, he published, along with close allies, a call for 'workers and the people' to establish a 'fifth international' [https://www.pambazuka.org/global-south/letter-intent-inauguralmeeting-international-workers-and-peoples] to coordinate support to progressive movements. To honor Samir Amin's invaluable contribution to world-systems scholarship, we are pleased to present readers with a selection of essays responding to Amin's final message for today's anti-systemic movements. This forum is being co-published between Globalizations [https://www.tandfonline.com/rglo], the Journal of World-Systems Research [http://jwsr.pitt.edu/ojs/index.php/jwsr/issue/view/75] and Pambazuka News [https://www.pambazuka.org/]. Additional essays and commentary can be found in these outlets.

Samir Amin was an animated spirit throughout his rich life. The essay he published just a month before his death calls for a new beginning of the left, for a new International. Amin's analysis is steadfast and his categories simple and uncompromising. He claims that capitalism always follows the same logic and concentrates power in ever fewer hands. Contemporary capitalism is vehemently upheld by the Triad (United States, Western and Central European countries, Japan). Amin declares that this system is totalitarian in all but name. 'The historical imperialist powers of the Triad have set 
up a system of collective military control over the planet.' This system amounts to an Orwellian permanent war waged by the West against the rest.

Amin concludes that the only possibility for liberation of 'the workers and the peoples' is to establish a worldwide Organization, a new International. Amin was an active participant in the World Social Forum (WSF) process, so he must have concluded that the WSF is hardly enough for worldwide transformation. He criticizes 'the extreme fragmentation of the struggles', making a tacit reference to various NGOs working locally on single issues such as ecology or women's rights. The new Organization must move 'beyond the concept of a discussion forum'. Moreover, the new Organization cannot be content with a horizontal form, rather it must involve some hierarchy. Adequate statutes can help to avoid the danger of non-democratic leaders.

In the famous afterword to the second German edition of Capital, Marx (1873) mentioned the possibility of discovering the rational kernel within the mystical shell of Hegel's philosophy. This is a good metaphor for thinking about Amin's proposal as well, although in this context a better adjective might be 'mythological' rather than 'mystical' (see also Amin, 2007, which is a much longer version of his proposal for a fifth International). Myths are stories that constitute worldviews. Stories are structured and they involve categories in terms of which these stories are told. It looks quite clear that Amin's story and fundamental categories have remained basically the same for several decades. For Amin, the analysis of the current world system is based on Lenin's theory of imperialism; and the main alternative to capitalism is an idealized version of Maoism, premised on delinking from the exploitative relations of the world capitalist system.

Lenin maintained that in capitalism the control over means of production will be ever more concentrated and centralized; banks and finance will play an increasingly important role. Because of the superabundance of capital in the highest stage of capitalism, and especially financial capital, capital turns outwards, resulting in new imperialism. A century later, Amin still concurs with Lenin's analysis. Nothing much has changed. Concentration and centralization continue. Contemporary globalization 'is nothing else but a new form of imperialist globalization'. Amin's view on representative democracy is essentially Leninist as well. Lenin (1917/1999, p. 28) thought that democracy is only a catchword 'with which the capitalists and their press deceive the workers and the peasants'. In a rather similar manner, Amin concludes in 2018 that 'representative democracy, having lost all its meaning, has lost its legitimacy'. Where Amin departs from Lenin is in his depiction of the role of the Triad, which resembles Karl Kautsky's notion of ultra-imperialism. Kautsky (1914/1970) envisaged that capitalist states would begin to co-operate after the Great War and govern the world in a concerted manner, also to prevent anti-imperialist forces from becoming too influential (the ultimate threat was socialism and the end of private property).

After Amin's arrival in Paris in the late 1940s, he joined the French Communist Party (PCF), but later distanced himself from Soviet Marxism and for some time was involved in Maoist circles (see 'Samir Amin', Wikipedia, version revised 22 December 2018). Later he was associated with various circles and organizations (e.g. he worked with the Ministry of Planning of the newly independent Mali 1960-1963 under Modibo Keïta's one-party socialist regime, which turned out rather disturbing to Mali's development); but it seems to me that an idealized version of Mao's China remained Amin's concrete utopia until the end of long career as a public intellectual.

Amin idealized the Maoist model in at least two distinct ways, through one-sided historical description and through normatively tendential counterfactual thinking. For Amin, Maoism was built on a worker-peasant alliance and on that basis, succeeded in realizing national self-sufficiency and egalitarianism. Amin (1981) claims that China's economic development was both impressive and benign in the period of 1950-80. From this standpoint, Amin criticized the 'revisionist' 
tendencies in China Deng Xiaoping became the de facto leader of China in 1978 turning China more openly toward world markets. A quarter of a century later Amin (2006) characterized China's opening in the 1980s as 'indispensable' to some degree, but still continued to praise the successes of Maoism. Amin also ignored, or at least downplayed, the violence of the Cultural Revolution. In the same vein, he did not cease to offer his public support for the Pol Pot regime in Cambodia even when the atrocities of Khmer Rouge were already widely known. As two scholars argued in the early 1980s in their reply to Amin's apparent responses to his critics:

Pol Pot and his regime were, it is clear, a gang of butchers, whose socialist aspirations and concern for the welfare of the Kampuchean people were demonstrated by genocide and torture. There is clearly no honest way in which Samir Amin can continue to evade this issue, since the 'principles' of 'socialist reconstruction' followed Amin's blueprint so closely. The only conclusion that Amin is not able to draw from the Kampuchean experience is that 'more of the same' is required in the 1980s, that future progress in Kampuchea requires the severing of relationships with Vietnam and the Soviet Union, so that socialism can be constructed on a suitably autarkic base. Such a conclusion can only be sustained by a refusal seriously to examine the consequences of autarkic strategies in the 1970s. (Smith \& Sender, 1983, p. 651)

Amin would have preferred a somewhat more democratic regime in Maoist China and in all likelihood also in Cambodia. He (2007, p. 128) stresses the 'democratic deficit' of national populist regimes. On the basis of wishful counterfactual thinking, it is possible to imagine a self-reliant national system that follows the basic tenets of Mao and Pol Pot without their despotic excesses (Amin continued to live in denial of the true extent of the violence in China and Cambodia). Amin's 2018 call for a fifth international does not significantly deviate from this pattern of thought. His last manifesto is an anti-imperialist text - whatever is meant by imperialism - but what is the positive future that it advocates? Amin is not arguing for world democracy, better global governance or world government; his project is not cosmopolitan. What Amin stresses is 'the necessary renewal of national, popular projects'. Therefore, he also criticizes those who use the term 'nationalism' negatively and, by the same token, seizes the opportunity to once again stress the importance of 'delinking':

The facile accusation of 'nationalism' of those critical of Europe does not hold water. The European project is increasingly visible as being that of the bourgeois nationalism of Germany. There is no alternative in Europe, as elsewhere, to the setting up of national, popular and democratic projects (not bourgeois, indeed anti-bourgeois) that will begin the delinking from imperialist globalization.

It is now time to return to Marx's famous afterword to the second German edition of Capital. Marx criticized Hegel for reducing everything to some sort of mystical Idea and for transfiguring and glorifying the existing state of things. This criticism can be applied to Amin. Amin assumes that Lenin can still provide the basic story about the nature of the existing world system ('mystical Analysis'), while he continues to transfigure and glorify the state of things in Mao's China. Marx demanded a thorough scientific, realist and critical analysis of ever-changing social realities. But there were mystical elements also within Marx's own thinking (Bhaskar, 1993, pp. 320-328), which Amin and other Marxists have inherited. For instance, most twentieth century Marxists assumed that social forms develop in stages and that capitalism will be followed by socialism (for half a century, this story survived the endless bifurcations of socialisms). Thus, there is no need to study systematically and critically different alternative possibilities and their likely consequences. Time and again, this has led to transfiguration and glorification of particular socialist and communist regimes, whatever their real effects and however repressive and violent they may have been. Amin (2007, p. 127, p. 132) 
makes critical comments about the third International and its orthodoxy of national single-party systems, but leaves the meaning of these paragraphs somewhat vague.

Amin's Leninist-Maoist vision - whether qualified in some ways or not - is unlikely to be persuasive to twenty-first century citizens. Nonetheless, there is a rational kernel in Amin's call for a new worldwide political organization. Starting with Amin's descriptive story, it is true that some structures, mechanisms and tendencies of the capitalist world economy are relatively enduring and some patterns recurrent, although the world economy is also fluid, constantly changing and evolving. Think about modern economic growth that started in the 1820 s and its consequences; rising but at times also declining inequalities; the growth of megacorporations since the 1860s; processes of financialization; and recurring business cycles and financial crises. In contrast to what Amin indicates, waves of globalization have radically transformed human societies and their economic activities during the past 500 years, also in many positive ways. Yet it is true, as Amin claims, that the expansion of the international society and world economy has repeatedly been characterized by violence, imperial subjection and colonial expropriation and exclusion.

There is a rational kernel also within Amin's analysis of the current world-political situation. Farmers, workers, employees, civil servants, entrepreneurs and citizens are far from being as mobile as goods, financial capital, wealthy individuals or megacorporations. Command over space and time is power and emancipation aims at freedom from domination. A mere discussion forum lacks transformative agency. The decline of the World Social Forum indicates that progressive politics must move 'beyond the concept of a discussion forum'. Amin also correctly criticizes 'the fragmentation of the struggles', as both local and global civil society activities have been dominated by single-issue politics. But it is equally important to highlight the positive aspects of civil society. As Bhaskar (1993, p. 325) argues in criticizing Marx, the social virtues of civil society involve 'a domain of innovation, initiative and enterprise necessary to a dynamic, pluralistic socialist society'. When the concept of societas civilis is employed globally it entails that civilizing processes, legality and politics are recognized as global in scope, and that there thus is a planetary civilization in the making. While these considerations are ignored by Amin, he correctly sees structureless anti-authoritarianism as disempowering. And yet Amin's alternative is ambiguous. His scepticism of (especially representative) democracy is not only unfounded but potentially dangerous. The new worldwide organizations must adopt methods of participatory will-formation and democratic procedures of collective decision-making. A sustainable democratic world society can only be created by democratic and peaceful means (see Patomäki, 2019a).

In its general social scientific meaning, globalization refers to the expansion of the field of social relations, and to the decreasing significance of physical and temporal distances. Globalization in this sense is not a thing, an actor, or a mechanism that explains much else apart from the possibility that social relations can be maintained with increasing ease and intensity across time and space. Moreover, globalization in the generic sense is not the same thing as imperialism, colonialism or neoliberalism, although these ideologies have characterized different waves of globalization (the current disintegrative tendencies in global political economy are consequences of the long process of neoliberalization; Patomäki, 2018). Globalization enables and constrains actors, shapes social relations and can be a part of a wide variety of geo-historical dynamics.

Consider for instance the anti-imperialist cosmopolitan imaginary that emerged in the latter half of the eighteenth century and early nineteenth century. It would have been very difficult to translate that imaginary into functional organizations of world governance or government (Patomäki \& Steger, 2010). Production remained based on land and agriculture; the speed of communication 
and transportation across the surface of the planet was limited to the velocity of humans, horses and sailing ships; many people were still willing to sacrifice their lives for the 'divine' rights of the dynastic rulers and aristocracy of particular communities; and the conditions of, say, income tax were only gradually emerging (the British introduced the world's first income tax to fund wars against Napoleon, only to be abolished in 1816). The planetary economy of the nineteenth century relied on the uncoordinated institutions of free trade, the gold standard, transnational finance and power-balancing (Polanyi, 1944/1957). The first functional international organizations proper were established only in the second half of the nineteenth century (for instance, the International Telegraph Union in 1865 to facilitate communications across the world).

The technological dynamism and industrial growth of the world economy have brought about novel global problems, as identified and framed by international organizations and other actors of transnational governance networks, and also novel opportunities. Current global problems include income and wealth disparities affecting access to things, relationships, and practices (Sayer, 2005); ecological problems such as global warming; and weapons of mass destruction. Our fates have become irreversibly intertwined. Awareness of this is part of our collective learning. Emancipation from unnecessary, unneeded and unwanted sources of determination requires both global transformative agency and planetary visions about progressive alternatives. This is the basis of my proposal for a world political party (Patomäki, 2011, 2019b). In a future world democracy, there will be many political parties and a vivid and pluralist civil society.

\section{Notes on contributor}

Heikki Patomäki is Professor of World Politics at University of Helsinki. His research interests include philosophy and methodology of social sciences; peace research; economic theory; global political economy, justice and democracy; and futures studies. His most recent book is Disintegrative tendencies in global political economy: Exits and conflicts (Routledge, 2018).

\section{Disclosure statement}

No potential conflict of interest was reported by the author.

\section{References}

Amin, S. (2007). Towards the fifth international? In K. Sehm-Patomäki \& M. Ulvila (Eds.), Global political parties (pp. 123-143). London: Zed Books.

Amin, S. (1981). The future of Maoism (N. Finkelstein, Trans.). New York, NY: Monthly Review Press.

Amin, S. (2006, September 21). What Maoism has contributed. Monthly Review. Retrieved from https:// monthlyreview.org/commentary/what-maoism-has-contributed/

Bhaskar, R. (1993). Dialectic. The pulse of freedom. London: Verso.

Kautsky, K. (1914/1970). Ultra-imperialism (Transl. unknown). New Left Review, 59, 41-46.

Lenin, V. (1917/1999). Imperialism: The highest stage of capitalism (D. Lorimer, Trans.). Sydney: Resistance Books.

Marx, K. (1873). Afterword to the second German edition (H. Kuhls, Trans.). Retrieved from https://www. marxists.org/archive/marx/works/1867-c1/p3.htm

Patomäki, H. (2011). Towards global political parties. Ethics \& Global Politics, 4(2), 81-102. Retrieved from http://www.ethicsandglobalpolitics.net/index.php/egp/article/view/7334

Patomäki, H. (2018). Disintegrative tendencies in global political economy: Exits and conflicts. London: Routledge. 
Patomäki, H. (2019a). Emancipation from violence through global law and institutions: A post-Deutschian perspective. In J. Kustermans, T. Sauer, D. Lootens, \& B. Segaert (Eds.), Pacifism's appeal. Ethos, history, politics (pp. 153-178). London: Palgrave MacMillan.

Patomäki, H. (2019b). A world political party: The time has come. GT (Great Transition) Network Essay, February 2019. Retrieved from https://www.greattransition.org/

Patomäki, H., \& Steger, M. (2010). Social imaginaries and Big History: Towards a new planetary consciousness? Futures, 42(10), 1056-1063.

Polanyi, K. (1944/1957). The great transformation. The political and economic origins of our time. Boston, MA: Beacon Press.

Sayer, A. (2005). The moral significance of class. Cambridge: Cambridge University Press.

Smith, S., \& Sender, J. (1983). A reply to Samir Amin. Third World Quarterly, 5(3), 650-656. 